Research Monograph Submitted as a Partial Fulfillment of ivaouc of Laws Degree Requirements

"Equality of Opportunities and Quota System in the Government Services of Bangladesh: A Rights-based Analysis."

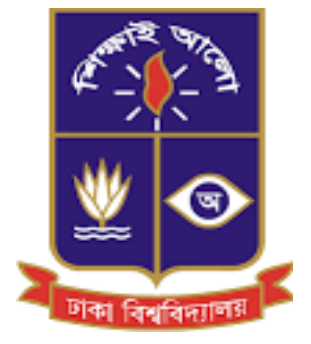

Course Code: 509

\title{
Course Name
}

\section{Human Rights and Development}

\section{Submitted to}

Chairman

Master of Laws Examination Committee

Department of Law

University of Dhaka

\section{Submitted by}

Mridha Mehedi Azam

$38^{\text {th }}$ batch LL.M.

University of Dhaka

of Submission: 30 August, 2016 


\section{Letter of Transmittal}

August 30, 2016

To,

Dr. Qazi Mahfuzul Haque Supan

Professor

Department of Law,

University of Dhaka.

Subject: Research Monograph on "Equality of Opportunities and Quota System in the Government Services of Bangladesh: A Rights-based Analysis."

Honorable Sir,

I would like to draw your kind attention towards the submission of my research paper. The paper is about "Equality of Opportunities and Quota System in the Government Services of Bangladesh: A Rights-based Analysis."

In this term paper, I have endeavored to incorporate the knowledge and experiences gained on a research level. I have tried to produce as well written and informative term paper as possible. This study has not turned out to be as informative as I would have preferred. Working on this project was a delightful experience for me as many unknown things were explored while working on the project.

I have tried my level best to complete the term paper with respect to the desired requirements. However, if any explaining is required, I would be honored to oblige. Kindly accept this humble effort of bringing forward my research and findings on the subject matter.

Sincerely Yours,

Mridha Mehedi Azam

Reg. No. H-3724

Session 2007-08 (38 ${ }^{\text {th }}$ Batch)

Department of Law,

University of Dhaka. 


\section{Acknowledgement}

At the beginning I remember the Almighty Allah to give me energy and patience to complete the Research Monograph. The research paper titled "Equality of Opportunities and Quota System in the Government Services of Bangladesh: A Rights-based Analysis."' is a requirement of my LL.M. Program. I have given my best efforts to focus the overall objectives and importance of the research monograph.

To prepare this research monograph, I was in need of some helps and guidelines. I am grateful to the writers of different books related to my research topic.

I am especially indebted to Dr. Quazi Mahfujul Hoque Supan, my course teacher, Human Rights and Development who has helped me a lot by supplying books, journals and other materials relating to my research topic and giving valuable instructions to complete the research.

I also convey my profound gratitude to all the teachers, Faculty of Law, University of Dhaka because their teaching in the last years in various courses has helped me to do this research monograph. I do hope this work will be helpful for the students of law, teachers, academicians and other interested persons. 


\begin{abstract}
The research is analyzing the effectiveness of existing Quota System in Public Service of Bangladesh to ensure Equality of Opportunity. I have divided my whole Research Monograph into five Chapters.

In the very first Chapter I have introduced the aims and objectives, scope, limitation and the methodology of the study. Then I have tried to reveal The Quota System in Bangladesh through discussing the evolution of Quota System and present status, implementing process and effect of quota system.

Then a brief idea has given about Equality of Opportunity and 'Rights based Model' in the following chapters by mentioning their nature and effect on society, necessity and obligation of implementing the principles arises out of this concept.

Then I have tried to examine the existing Quota System in Government Services of Bangladesh whether it is compatible with the principles of 'Rights based Model' and capable of ensuring Equality of Opportunity. Finally there are some recommendations to ensure equality of opportunity in Public Service through amending exiting quota System.
\end{abstract}


Table of Contents

\begin{tabular}{|c|c|}
\hline Topics & Page \\
\hline Chapter-One & 7-8 \\
\hline 1.1 Introduction & 7 \\
\hline 1.2 Aims and Objectives of the study & 7 \\
\hline 1.3 Fields/ Scope of the study & 7 \\
\hline 1.4 Methodology & 8 \\
\hline 1.5 Coverage and Limitations & 8 \\
\hline Chapter-Two & 9-15 \\
\hline 2.0. Introduction & 9 \\
\hline 2.1. Definition & 9 \\
\hline 2.1.1. Quota System in Bangladesh & 9 \\
\hline 2.2. Historical Background of Quota System & 9 \\
\hline 2.3. Evolution of Quota System in Bangladesh & 10 \\
\hline 2.4Present Quota system in Bangladesh Public service & 13 \\
\hline 2.4.1. Freedom Fighter Quota & 13 \\
\hline 2.4.2. Women Quota & 13 \\
\hline 2.4.3. District Quota & 13 \\
\hline 2.4.4. Tribal quota & 13 \\
\hline 2.4.5. Handicapped quota & 13 \\
\hline 2.4.6 Bangladesh Judicial Service Commission (BJSC) & 14 \\
\hline 2.4.7. Quota in public, in class (3) \& (4) & 14 \\
\hline $\begin{array}{l}\text { 2.4.8. Quota in others semi government and autonomous } \\
\text { organization }\end{array}$ & 14 \\
\hline 2.4.9. Implementation process of existing quota system & 14 \\
\hline 2.4.10. Debate around the present quota system & 15 \\
\hline 2.5. Conclusion & 15 \\
\hline Chapter-Three & $16-22$ \\
\hline
\end{tabular}




\begin{tabular}{|c|c|}
\hline 3.0. Introduction & 16 \\
\hline 3.1.Meaning & 16 \\
\hline 3.2. Principle of Non-Discrimination & 17 \\
\hline $\begin{array}{l}\text { 3.3. Impact of ensuring equality of opportunity and } \\
\text { principle in non-discrimination of society: }\end{array}$ & 18 \\
\hline 3.3.1. Favourable work Environment & 18 \\
\hline 3.3.2. Transparency and accountability & 18 \\
\hline 3.3.3. Protection for all & 18 \\
\hline 3.3.4. Ensure Quality & 18 \\
\hline 3.3.5. Distribution of wealth among citizens of the state & 18 \\
\hline 3.3.6.Law and Order Situation & 19 \\
\hline 3.3.7 Others & 19 \\
\hline $\begin{array}{l}\text { 3.4. International instruments ensuring Equality of } \\
\text { Opportunity }\end{array}$ & 20 \\
\hline $\begin{array}{l}\text { 3.5. .Equality and Non-Discrimination Provision under } \\
\text { Constitution of Bangladesh }\end{array}$ & 21 \\
\hline 3.6. Vulnerable People & 21 \\
\hline 3.7.Conclusion & 22 \\
\hline Chapter-Four & $23-33$ \\
\hline 4.0. Introduction & 23 \\
\hline 4.1.Definition of Right based Opportunity & 23 \\
\hline 4.2. Freedom Fighter Quota & 23 \\
\hline $\begin{array}{l}\text { 4.2.1. Whether the Quota provisions for Freedom Fighter is } \\
\text { Universal? }\end{array}$ & 24 \\
\hline $\begin{array}{l}\text { 4.2.2. Whether the Freedom Fighter Quota in Bangladesh } \\
\text { Public Service is Compatible with the Principle } \\
\text { 'Participation and Inclusion' of right based approach }\end{array}$ & 24 \\
\hline $\begin{array}{l}\text { 4.2.3. Whether the existing "freedom fighter quota" in } \\
\text { compatible with the principle of non-discrimination }\end{array}$ & 25 \\
\hline $\begin{array}{l}\text { 4.2.4. Whether the freedom fighters can be considered as } \\
\text { vulnerable person }\end{array}$ & 25 \\
\hline
\end{tabular}




\begin{tabular}{|c|c|}
\hline $\begin{array}{l}\text { 4.2.5. Whether representation from freedom fighters as } \\
\text { well as their wards are actually been filled up by the true } \\
\text { freedom fighters on their wards? }\end{array}$ & 25 \\
\hline $\begin{array}{l}\text { 4.2.6. Whether quota system is compatible with the spirit of } \\
\text { our great liberation war }\end{array}$ & 25 \\
\hline 4.3. District Quota & 26 \\
\hline 4.3.1. Whether the 'District Quota' is universal & 26 \\
\hline $\begin{array}{l}\text { 4.3.2. Whether the districts that are considered backward } \\
\text { are getting proportionate representation? }\end{array}$ & 26 \\
\hline $\begin{array}{l}\text { 4.3.3. Whether the person who is getting the quota facility } \\
\text { from the backward district is coming from a poor family or } \\
\text { is from a well off family }\end{array}$ & 27 \\
\hline 4.4. women quota & 27 \\
\hline $\begin{array}{l}\text { 4.4.1. Whether the allocated quota in public service is } \\
\text { functioning as a tool of removing discrimination towards } \\
\text { woman? }\end{array}$ & 28 \\
\hline $\begin{array}{l}\text { 4.4.2. Whether the selected women in civil service under } \\
\text { quota provision are from educated and privileged? }\end{array}$ & 29 \\
\hline 4.5. Tribal Quota & 29 \\
\hline $\begin{array}{l}\text { 4.5.1 Whether the Tribal Quota being filled by the all Tribes } \\
\text { Proportionate to the particular Tribes Population size to } \\
\text { the total population }\end{array}$ & 30 \\
\hline $\begin{array}{l}\text { 4.5.2. Whether the allotted percentage for Tribal } \\
\text { community is adequate? }\end{array}$ & 30 \\
\hline 4.6. Handicapped Quota & 31 \\
\hline 4.7. Overall Evaluation of quota system & 31 \\
\hline $\begin{array}{l}\text { 4.8. Status of the largest portion who are recruited in } \\
\text { public service on basis at merit }\end{array}$ & 32 \\
\hline 4.9. Conclusion & 32 \\
\hline Chapter-Five & 33 \\
\hline 5.1.Recommendations & 33 \\
\hline 5.2. Conclusion & 33 \\
\hline Bibliography & 34 \\
\hline
\end{tabular}




\section{Chapter One}

\section{Introductory}

\subsection{Introduction:}

Bangladesh is a nation state which is emerged in world map through a historic struggle of national liberation in 1971. The vision of the struggle was to establish an exploitation free society.

Among many others expectation of citizens at a state who is going under a transitional period of development after liberation 'Equality and Opportunity' in getting Government job is highly expected rather demanding as a fundamental rights. But job seekers of Bangladeshthe most potential and meritorious groups are become frustrated day by day by being deprived of getting expected Government job despite having enough qualifications.

Besides over population and scarcity of positions in Public Service the debated 'Quota system' in Government Services in Bangladesh is the key factor in this regard.

With many other legislation of British-India and Pakistan, Quota provisions were adopted in newly liberated Bangladesh which is still exist with almost same nature after 45 years of liberation .Some Amendments of this quota system without considering Expert Reports and being politically motivated makes the system complex and discriminatory and debated.

In this study the legal and socio-economic status of this said Quota System will be examined in following chapters though discussion of Quota System and its history, Present scenario of the system and implementing process, Concept of 'Equality of Opportunity' and principles of 'Rights based Models' .Relationship among Equality of Opportunity and Quota System.

Hopefully the study will reveal the actual scenario and able to put recommendations for overcome the barriers on establishing 'Equality of Opportunity' in Government Services in Bangladesh imposed by existing Quota System.

\subsection{Aims and Objectives of the study:}

The present study mainly aims to examine the compatibility of existing Quota system and Equality of Opportunity in Government Services of Bangladesh with the principles of 'Rights based Model' through evaluating the following.

Dhether the existing Quota System is able to ensure Equality of Opportunity?

$>$ To discover the relation between 'Equality of Opportunity' and 'Quota System' in Bangladesh.

$>$ Reveal the reasons behind the debate around Quota System in Bangladesh and focuses on the solutions of that problem.

\subsection{Fields/ Scope of the Study:}


A large number of Research and News paper Article has published in different dimension around the debate regarding existing Quota System in Government Services in Bangladesh. Still there a scope to do research with this debated 'Quota System' in light of 'Rights based Model for seeking answers. Whether it is enabling to ensure Equality of Opportunity in legal perspective?

\subsection{Methodology:}

This study uses mostly from secondary source. Secondary source includes annual reports published by the Public Service Commission, Reports on Administrative Reorganization/Reform Commission etc. Moreover papers prepared by donor agencies and potential researchers have been extensively used. Some Cabinet papers and reports on Quota System have been consulted. Apart from the above, Personnel Data System of the officers preserved in public Administration Computer Control of the Ministry of Public Administration has been used. It also used primary data based on personal experience and reactions of officials associated with the recruitment process of the Public Sector.

\subsection{Coverage and Limitations:}

The present study does not necessarily take into consideration the context of other services I. e. the services of constitutional bodies, the services of statutory organization. It only looks at the cadre services of the Republic. It also looks at some selected data as explained hereunder. This study contains data of Central Superior Service of Pakistan, Control Superior Service, East Pakistan Civil Service and Civil Service officers recruited after independence of Bangladesh. Furthermore, I feel a shortage of detail data as it is not available in BPSC website and not possible to collect in alternative way due to shortage of time. A Chapter including opinion of the concerned parties may enrich the research which has not possible due to word limitation and time frame. 


\section{Chapter Two}

\section{Quota System}

\subsection{Introduction:}

In this chapter the Quota System in public service will be revealed through discussion of Quota System, present Quotas in Bangladesh public service and later focus on the impact of this system in Right base perspective.

\subsection{Definition:}

In general sense "Quota System" refers to a reservation process for specific community (backward section) to ensure some rights or facilities to uphold their position or to make sure their representation in that very sector.

According to dictionary.com, Quota means "A hiring or admission policy requiring that a specific number or percentage of minority group members be hired or admitted". '

In legal perspective, "a Quota System, in the employment context, is a hiring system that gives preferences to protected group members, Quota System are designed to correct adverse impact, resulting from employment practices that appear neutral but have a discriminatory effect on a protected group." ${ }^{2}$

So it can be said that Quota is a mechanism to serve the backward community with some short of basic needs like education, employment, health care facilities and so on.

\subsubsection{Quota System in Bangladesh:}

In Bangladesh perspective there is no specific definition of Quota. Whereas it exists in many socio-economic sphere of the country.

The Quota System in Bangladesh acquire its legal basis from the Article 29(3)(a) and article 28(4)of The Constitution of Peoples Republic of Bangladesh where these articles empowers the legislative authority to make provision in favor of backward sections of citizens, women and children for the purpose of securing their adequate representation in the service of the republic.

Provided that, the system was initiated to ensure 'equality of opportunity' before public service as per the basic theme of this article. Utilizing this power conferred by constitution Governments of Bangladesh time to time make several executive order and rules imposing quota system in many socio-economic sphere of the country. Rather other sectors of existing quota system in this article the focus will be centered on the quota system in public service in Bangladesh.

\subsection{Historical Background of Quota system:}

The administrative structure and civil service System of Bangladesh is inherited from Pakistan, which was a continuation of the System of the British India. For this reason like

\footnotetext{
${ }^{1}$ http://www.dictionary.com/browse/quota

${ }^{2}$ http://definitions.uslegal.com/q/quota-system/
} 
other administrative practice of British India and then Pakistan Quota system is inherited in Bangladesh.

As a continuation of an executive order immediately after 1947 and afterwards CSP and Cadre Rules $1954^{3}$ the constitution of 1956 of then Pakistan ensure protection against discrimination on ground of race, religion, caste or sex, residence or place of birth. ${ }^{4}$

Initially the safeguard was given for a term of 40 years from the said constitution day, but it had been continued as CSP in the following form given in the Chart below:

Chart:: Recruitment in Central Superior Service (CSS) ${ }^{5}$

\section{Recruitment in Central Superior Service(CSS) East Pakistan}

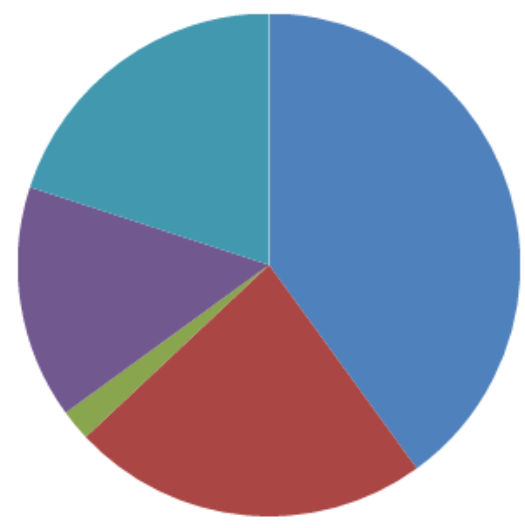

Panjab and Bhawalpur

Sind, Khairpur, North West proviences Frontier, Tribal Areas, Baluchistan Azad K ashmir

Refuges

The Quota was distributed on the basis of population of the provinces because of the existing disparity among the provinces of Pakistan in ground of socio-economic perspective.

After being liberated from Pakistan through a bloody liberation war in 1971 in order to encounter other pressing reasons Bangladesh has adopted Quota System through an executive order in 1972.

\subsection{Evolution of Quota system in Bangladesh:}

The first step of reserving quota in newly liberated Bangladesh was put forward through the Interim Recruitment Policy, $1972^{6}$ in order to ensure representation of the people of every corner of the country and every sphere of society in the public service and also to evaluate the sacrifice and braveness of the freedom fighters they can contribute with their immense potential and patriotism to rebuild the newly liberated Bangladesh with a view to addressing freedom fighters sacrifice as well as involving them in nation building $30 \%$ of the total position of the public service for the freedom fighters and $10 \%$ position for the war affected

\footnotetext{
${ }^{3}$ The CSP and Cadre Rules, 1954 commenced on 01.06.1954

${ }_{5}^{4}$ Article, 27 of the Constitution of the Islamic Republic of Pakistan of 1956

${ }^{5}$ Kennedy, 1987 in Ali 2004

${ }^{6}$ Bangladesh Public Service Order, 1972, (Order no: Estt/RI/R-73/72-109(500), dated $5^{\text {th }}$ September 1972).
} 
women were reserved. Another $40 \%$ of the position was reserved for the district based on their population as a continuation of the previous quota system of Pakistan. Rest of the $20 \%$ of total position was filled with merit basis. A amendment had done in 1976 by adjusting the reserved amount of District Quota and Merit Quota. Following charts show the Reservation System of 1972 and 1976.

\section{C}

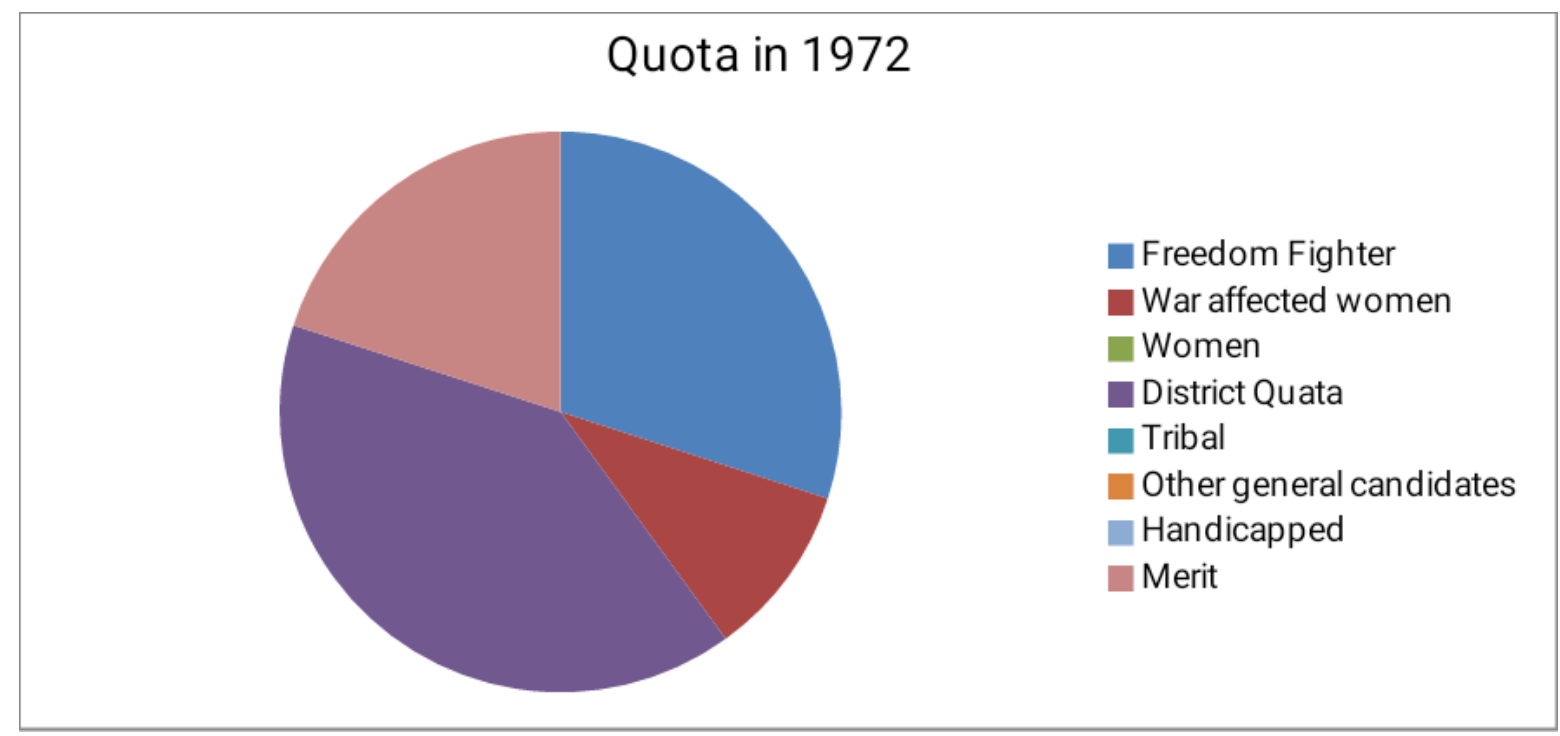

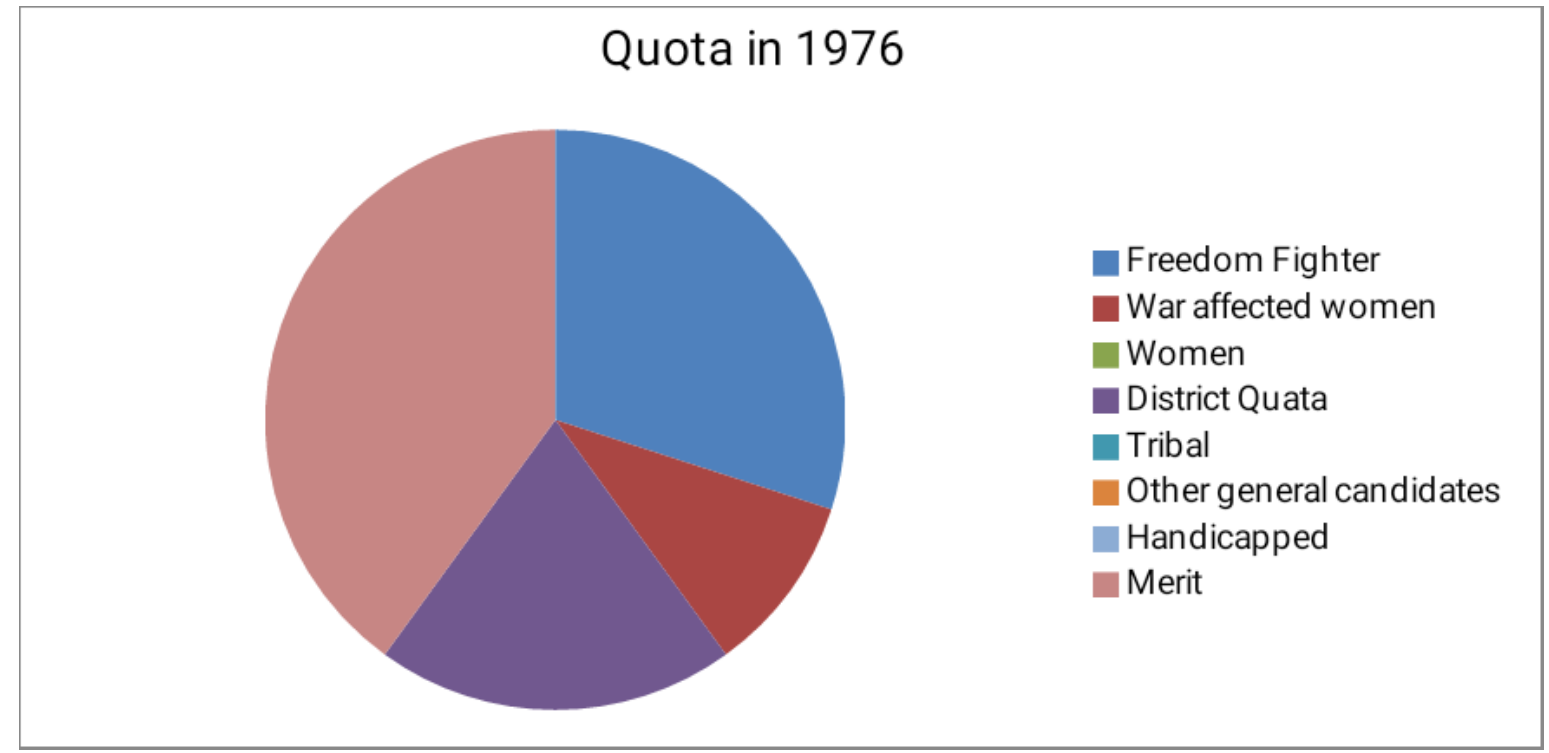

In practice, no war affected woman was found to recruit under the quota. As a consequence, the system was rearranged in $1985^{7}$ abolishing war affected woman quota. The revised allocation was $45 \%$ for merit, $30 \%$ for freedom fighters, $10 \%$ for women, $5 \%$ for tribal and other general candidates of the districts.

\footnotetext{
${ }^{7}$ Bangladesh Civil Service (Age, Qualification and Examination for Direct Recruitment) Rules, 1982
} 


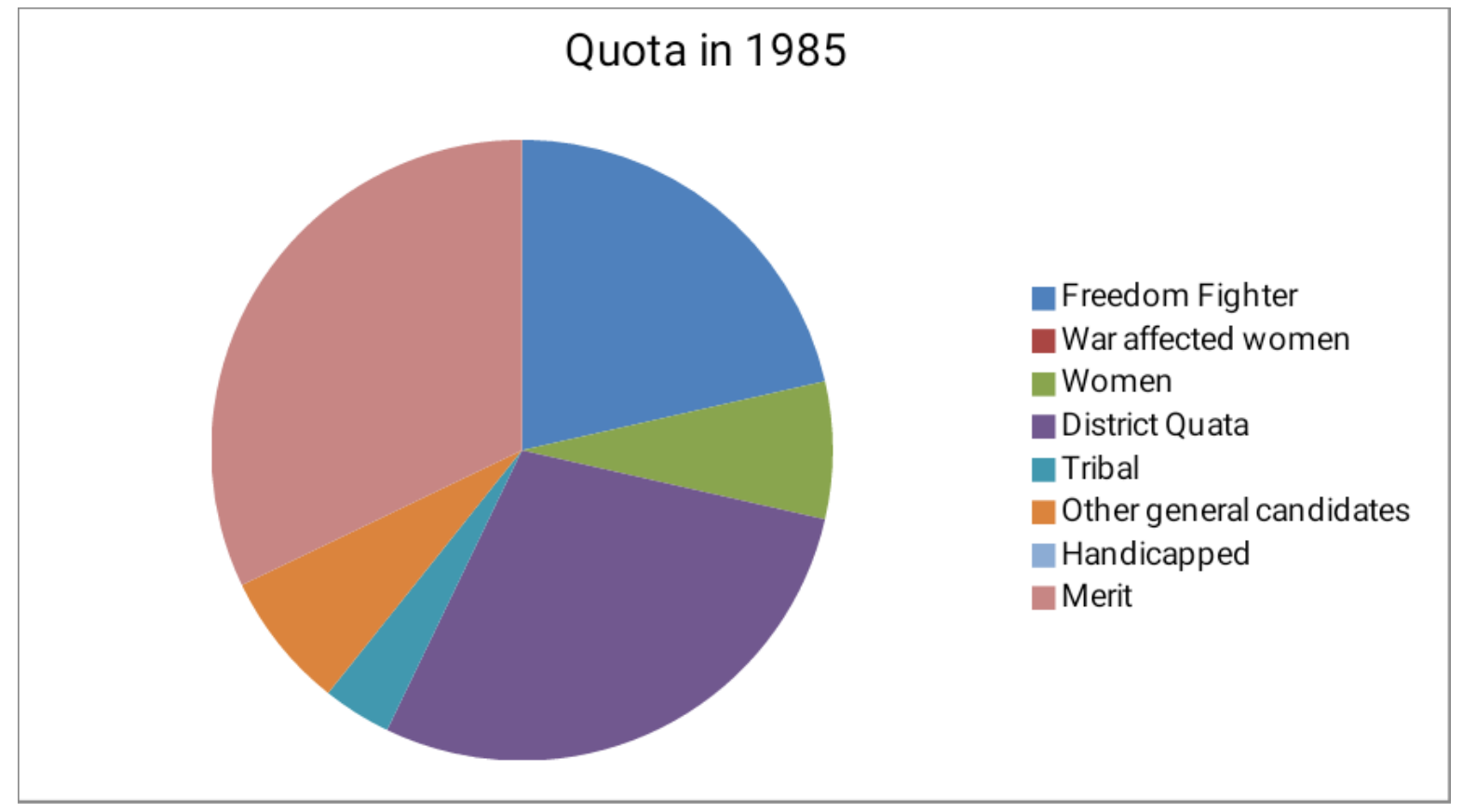

Another reforms in quota system has down in 1997 which added additional features on 1985 's format in freedom fighters quota that "If sufficient number of freedom fighters were not available the reserved position of them were earmarked for their wards" ${ }^{\prime 8}$ issues of freedom fighters were also was eligible for the reserved freedom fighters quota.

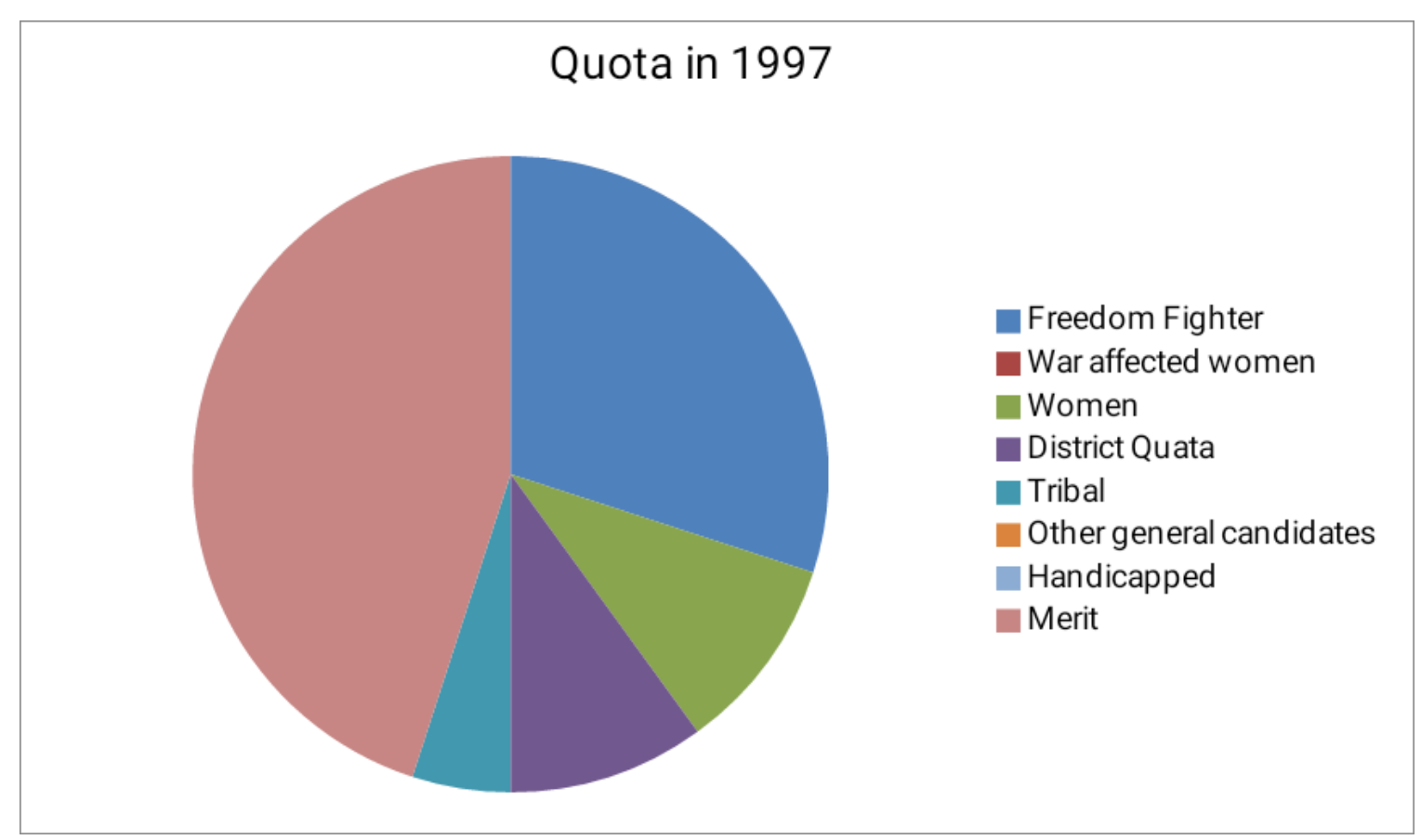

Lastly a change has been initiated by adding additional $1 \%$ quota for the Handicapped people as per the high court instruction ${ }^{9}$ and government rules in $2012^{10}$.

\footnotetext{
${ }^{8}$ Government of Bangladesh (1997), Report of the Pay and Service Commission, Part-1, Cabinet Division, Dhaka. ${ }^{9}$ BLAST and others v Bangladesh and others ['PSC Disability Discrimination' Case] Writ Petition No. 2932 of 2010 ${ }^{10}$ BPSC Circular, memo no-05.00.0000.170.07.057.11-15, dated 12.01.2012.
} 


\section{4: Present quota system in Bangladesh Public Service:}

$55 \%$ of total position is reserved under quota provision for several quotas which are discussed below.

\subsection{1: Freedom Fighters quota:}

Freedom fighters quota was initiated for the sake of including our brave freedom fighters in nation building process. Whereas after 45 years of liberation their Issues and Grand Children are enjoying $30 \%$ quota in public service with a consecutive priority basis.

\subsection{2: Women quota:}

In applying the provision of Article, 28 (4) of Bangladesh Constitution women quota was initiated in 1985 in place of War Affected Women's quota and still remains 10\% reservation in public service.

\subsection{3: District quota:}

District or Region base quota was historically initiated to remove disparity in socio economic level. Though Bangladesh has a homogenous nation being reduced District Quota still exists as second largest position together with women quota having $10 \%$ reservation in public service.

\subsection{4: Tribal quota:}

Tribal Quota was first initiated in 1985 and still exists having 5\% reservation in public service.

\subsection{5: Handicapped quota:}

Conditional Quota of $1 \%$ is reserved for the Persons with Disabilities (PWDs) that if the positions were remain vacant of the reserved 55\% Quota then the PWDs will eligible to get reservation of $1 \%$ positions out of those vacant positions.

The above quota distribution is maintained in recruitment of cadres by BPSC but some other institution including BPSC itself in recruiting some other positions of public service apply quota system quite differently.

Current Quota Distributions are shown in the chart below 


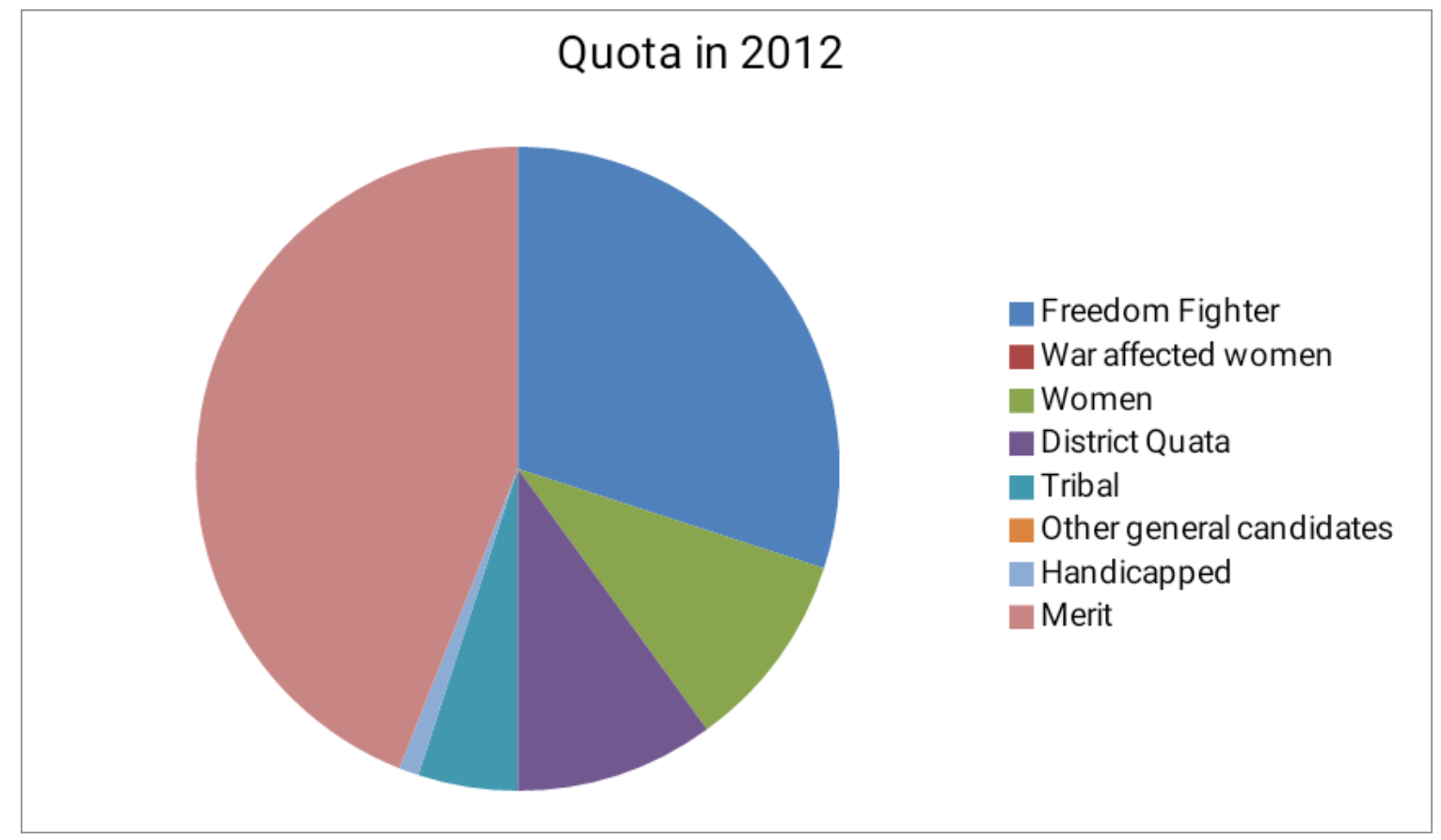

\subsection{6: Bangladesh Judicial Service Commission (BJSC):}

BJSC is dedicated in recruitment judges in Bangladesh Judicial Service which was previously done by BPSC as an integrated process through BCS examination. After separation of judiciary in 2007 BJSC, has been formed with the very purposes. But BJSC does not follow the total Quota provisions of BPSC by excluding Handicapped Quota, further more excluding them from sitting the exam also.

\subsection{7: Quota in public service, in class (3) \& (4):}

$30 \%$ of total position are reserved for freedom fighters as well in (3) \& (4) class public service besides other allocated reservations are- $10 \%$ for physically Handicapped peoples, $15 \%$ for women, $5 \%$ for tribal, $10 \%$ for Ansar/village defense members and remaining $30 \%$ for general candidate of districts distributed as per population ratio.

\subsection{8: Quota in others semi government and autonomous organization:}

All Nationalize Bank and Financial Organization and some other semi-Government and autonomous institution now follow in the last updated quota format and ensure reservation of $55 \%$ positions for the quota holders.

\subsection{9: Implementation process of existing quota system:}

Though it looks simple but the true fact is ensuring present quota system goes under a complex procedure.

First of all allocated 50\%(except Tribal Quota) reserved positions are distributed among the district according to their population ratio, then prescribed percentage of reservations are distributed among stakeholders of the quota, provided that in case of non availability of freedom fighters quota to the Issues of Freedom Fighters are entitled to enjoy the 
reservation. Further provided that, if no such enough candidates are found the Grand Children of the freedom fighters will preferred for the positions. If position remain vacant, after following above stages then PSC can time to time arrange special BCS to fulfill those vacant post. In true sense every time fractional figure comes in distributing prescribed quota among the stakeholders in prescribed manners.

\subsubsection{0: Debate around the present quota system:}

There is a huge debate around the existing quota system in and outside Government regarding the said percentage of $55 \%$ reservation, implementing process, necessity of district quota and status of vacant post due to non-availability of required candidates.

The BPSC itself acknowledging the fact, prescribed in its annual report 2009 \& 2011 recommended bringing reforms to the system saying the policy was complicated and difficult to implement. ${ }^{11}$

The reports say "because of the complex quota system is almost impossible to select the right candidates with $100 \%$ accuracy". ${ }^{12}$

Besides, BPSC all the "Expert Commissions" formed by the successive Government opposed the quota system. ${ }^{13}$

In an interview with Daily Star former cabinet secretary Akbar Ali Khan said "quota should not be exceed $50 \%$ of Government jobs and they cannot exist forever" ${ }^{14}$

There is a mass frustration over the quota system among the millions of jobs seekers which was burst several times even through violent demonstration.

\subsection{Conclusion:}

So the common question around the quota system in public service in Bangladesh is whether the system is enabled to fulfill its very perspective of ensuring equality of opportunity in public service by serving special facilities to backward community?

Before analyzing the question in right base model the concept of equality of opportunity has discussed in the next chapter.

\footnotetext{
11 BPSC Annual Report, 2009 \& 2011.

12 BPSC Annual Report, 2009 \& 2011.

${ }^{13}$ Daily Star july 13,2013 , in the article 'govt ???? PSC recommendation by wasim bin habib and protic chacroborty

${ }^{14}$ Daily Star july 13,2013 , in the article 'govt ???? PSC recommendation by wasim bin habib and protic chacroborty
} 


\section{Chapter- Three \\ Concept of Equality of Opportunity}

\subsection{Introduction:}

In this chapter the concept of "Equality of Opportunity", Principle of Non-Discrimination, National and International instrument of ensuring equality of opportunity and the provisions for the vulnerable groups will be discussed consecutively.

\subsection{Meaning of Equality of Opportunity:}

To understand the concept of 'equality of opportunity' it is necessary to understand the difference of it from 'equal opportunity'. Following image can best describe the difference between equal opportunity and equality of opportunity-

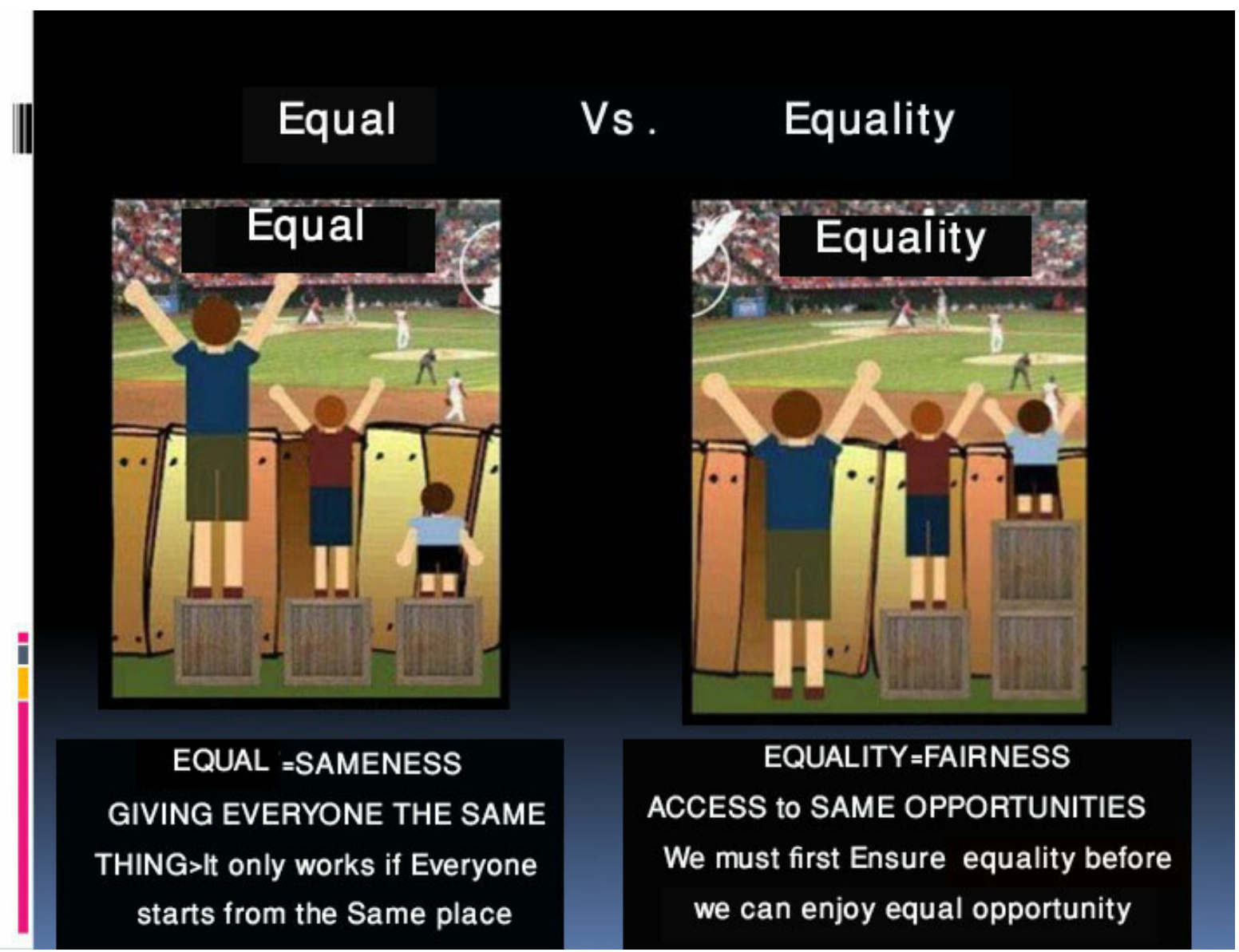

The idea of formal equality can be described in Aristotle's voice that "equality means things those are allied should be treated alike"15

This idea can be desceibed as a 'treacherously simple concept ${ }^{\prime 16}$

\footnotetext{
${ }^{15}$ Aristotle, 3 EthicaNicomachea, 112-117, 1131a-1131b, Ackrill, J. L. and Urmson J. O. (eds.), W. Ross translation, Oxford University Press, 1980

${ }^{16}$ Holtmaat, Rikki. "The Concept of Discrimination", Academy of European Law Conference Paper, 2004, p.2, (available at: http://www.era.int/web/en/resources/5_1095_2953_file_en.4193.pdf), last
} 
The very meaning of equality of opportunity refers to the opportunity of equal access to employment and other socio-economic opportunities which is ensured by major human Rights instrument and constitutions across the world. Subsequently this right is related with Right to Life, where right to life includes every aspect of human life that is needed for his or her survival as a human being with dignity. Dignity is an inexorably related with human development. All other human rights is based on human dignity ${ }^{17}$

A broad definition of the term right to life has been given in the case of Mohiuddin Farooque, $^{18}$

"Right to life is not only limited to the protection of life and limbs but extends to the protection of health and strength of workers, their means of livelihood, enjoyment of pollution free water and air, bare necessaries of life, facilities for education, development of children, maternity benefit, free movement, maintenance and improvement of public health by creating and sustaining conditions congenial to good health and ensuring quality of life consistent with human dignity.

So Equality of Opportunity means guarantee of ensuring rights to live with dignity as a human being.

\section{2: Principle of Non-Discrimination:}

Non-Discrimination in general sense is the counter part of discrimination that broadly refers to exclude any distinction which is based on any ground such as race, color, sex, language, religion, political or other opinion, national or social origin, property, birth of other status. But if the principle of non-discrimination has merged with equality of opportunity than a critical valuation demands that "Are all distinctions constitutes discrimination"?

This is summed up by the axiom, "people who are equal should be treated equally and those who are different should be treated differently ${ }^{19}$ because there such situation exists that distinction may be treated as non-discriminatory. In other words it can be termed as "fair discrimination" international law establishes criteria for determining when a distinction amount to discrimination. A judgment by the European court in Belgium linguistic case ${ }^{20}$, it was held that, "Not all types of differential treatment in the provision of rights and freedoms constitute prohibited discrimination under the convention" In this judgment the court set fourth its analytical scheme for determining when prohibited discrimination has occurred:

a. The facts disclose a differential treatment

\footnotetext{
accessed $17^{\text {th }}$ March, 2016.

${ }^{17}$ Universal Declaration on Human Rights (adopted 10 December 1948) UNGA Res 217 A(III) (UDHR), Preamble, International Covenant on Civil and Political Rights (adopted 16 December 1966, entered into force 23 March 1976) 999 UNTS 171, Preamble; Cossey v UK [1990] Series A No. 184[2.7]; UDHR,art 22;

${ }^{18}$ MohiuddinFarooqueVs. Bangladesh and others, 48 DLR HCD 438.

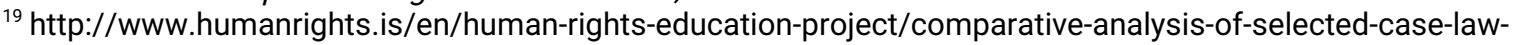
achpr-iachr-echr-hrc/the-right-to-equality-and-non-discrimination/concept-and-importance-of-the-principle-of-nondiscrimination

${ }^{20}$ case 'Relating to Certain Aspects of the Laws on the Use of Languages in Education in Belgium , Application Nos. 1474/62, 1677/62, 1691/62, 1769/63, 1994/63, 2126/64, Judgements of 23 July 1968)
} 
b. The distinction doesn't have an aim, that is, it has no objectives and reasonable justification having regard to the aim and effects of the measure under consideration and

c. There is no reasonable proportionality between the means employed and the aim sought to be realized.

Thus the distinction having a particular aim specially to ensure equality in opportunity beyond arbitrariness is considered as non-discriminatory distinction or positive discrimination.

3.3: Impact of ensuring equality of opportunity and principle of non-discrimination in society:

An ideal society is such a society where people don't suffer from discrimination based on ethnicity, race, religion, sex, etc. Equal Opportunity is a stipulation that all people should be treated similarly unhampered by artificial barriers or prejudices on preference, except when particular distinction can be explicitly justified ${ }^{21}$ by assuring equality of opportunity a particular society or nation can gain following socio-economic characteristics.

\subsubsection{Favourable working Environment:}

It enacts a fair environment in getting any work or job beyond their ethnic or socio-economic dissimilarity to which they belong. People from every sphere of society can get their job according to their merit. Thus it creates a favourable working environment by removing discrimination in case of getting public jobs or promotion in their jobs.

\subsection{2: Transparency and Accountability:}

The decision making and implementation process of such decision become more transparent and the concern authority come under accountability through ensuring equality of opportunity.

\subsection{3: Protection for all:}

Equality of Opportunity impose barrier to make any types of artificial and arbitrary obstacles for the purpose of preventing person from applying and achieving any job or public position which they deserve. In this way it ensures the protection for all level of society to enjoy their right to employment.

\subsection{4: Ensure Quality:}

Through ensuring equality of opportunity in every job sector of the country, the job and other important public positions shall be occupied by the most qualified persons and it is very

\footnotetext{
${ }^{21} \mathrm{http} / / /$ plato.stanford.edu/entries/equal-opportunity/llowing, last accessed $17^{\text {th }}$ March, 2016
} 
reasonable to expect that when the qualified holds the important positions than they shall act with their skillful mind and try their best to bring the highest success of their specific sector or department and in this way the overall development of the country can be ensured.

\subsection{5: Distribution of Wealth among citizens of the State:}

The distribution of wealth is a comparison of the wealth of various members or groups in a society. It differs from the income distribution in that it looks at the distribution of ownership of the assets in a society, rather than the current income of members of that society. Wealth inequality can be described as the unequal distribution of assets within a population ${ }^{22}$. A study by the 'World Institute for Development Economics' Research at United Nations University reports that the richest $1 \%$ of adults alone owned $60 \%$ of global assets in the year 2014 , and that the richest $10 \%$ of adults accounted for $95 \%$ of the world total. The bottom half of the world adult population owned $1 \%$ of global wealth. Moreover, another study found that the richest $2 \%$ own more than half of global household assets ${ }^{23}$. It is a clear example of absence of equality of opportunity, if all people have the equal opportunity and treat as equal the wealth will not stored in hand of only few numbers of people. So equal opportunity is very much important to the equal distribution of wealth.

\subsection{6: Law and Order Situation:}

Normally mass people are respectful toward law. But in a society where disparity exists regarding ethnicity and other socio-economic matters, maintaining law and order situation in that society is a great challenge .as because the deprived groups often get furious and involve with the criminal activity. But if it is possible to ensure equality of opportunity like others then he may try to take that opportunity to develop his condition. Which can necessarily reduce the risk of hampering law and order situation?

\subsection{7: Others:}

Equality of opportunity may ensure some other important features given below.

$>$ Ensure equal development of all communities.

$>$ Ensure women participation in all spheres.

$>$ Ensure participation of all classes.

Help to emergence of various welfare ideas and thoughts.

$>$ Diminish the concept of superiority and inferiority.

$>$ Encourage all people to go forward by performing their own duty.

\subsection{Internation instrument ensuring Equality of Opportunity:}

\footnotetext{
${ }^{22}$ Constitution of the People's Republic of Bangladesh, Article 19.

${ }^{23}$ James B. Davies, Susanna Sandstrom, Anthony Shorrocks, and Edward N. Wolff. "The World Distribution of Household Wealth".
} 
The major instrument which has adapted and practiced internationally to ensure Equality of opportunity are tabled below

\begin{tabular}{lll}
\hline Sl. & Name of the Instrument & Relevant Articles/Provisions
\end{tabular}

No.

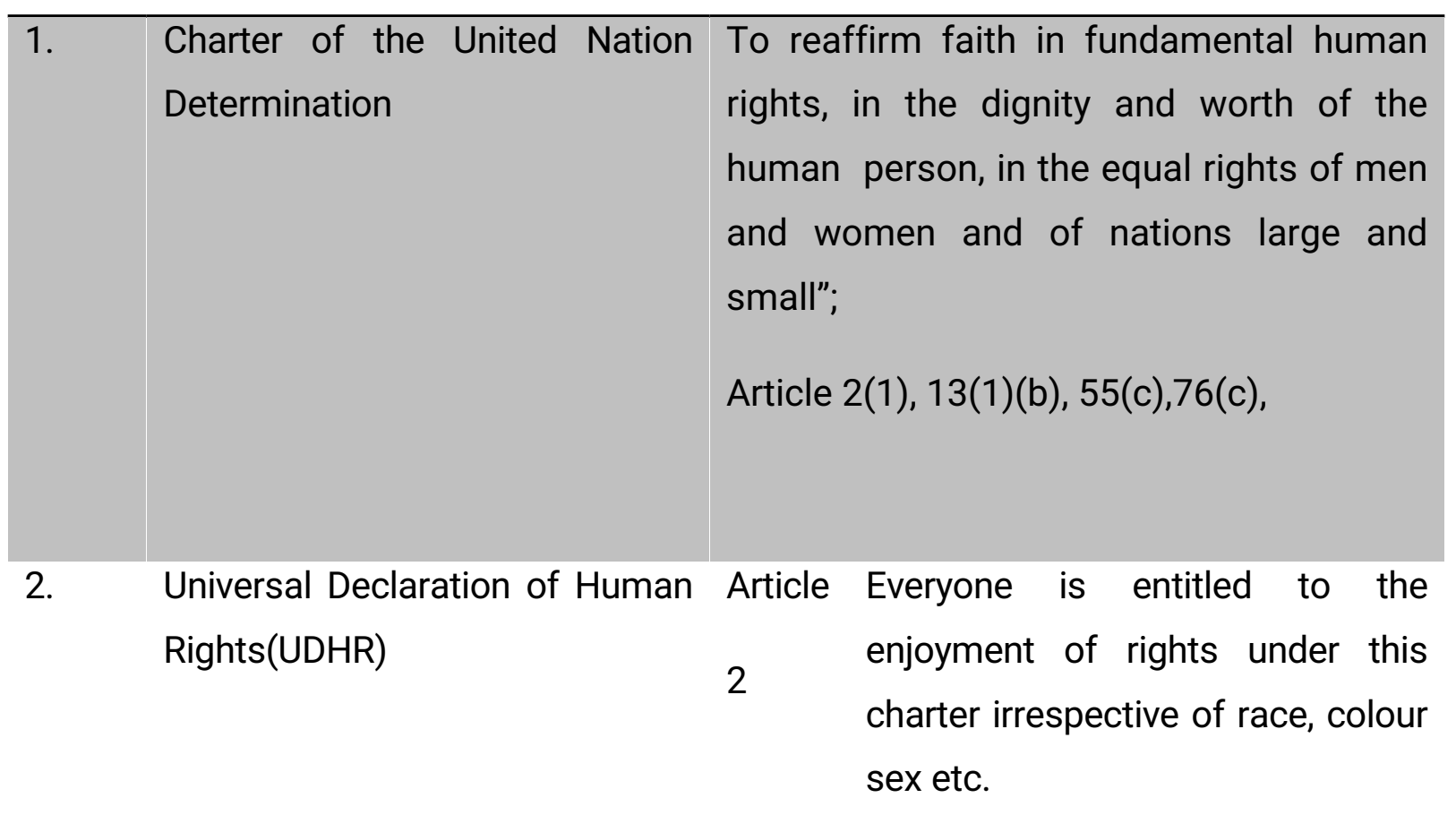

Article Equality and Equal Protection of

7 Law

3. International Covenant on Civil Article Prohibition on Discrimination and Political Rights (ICCPR)

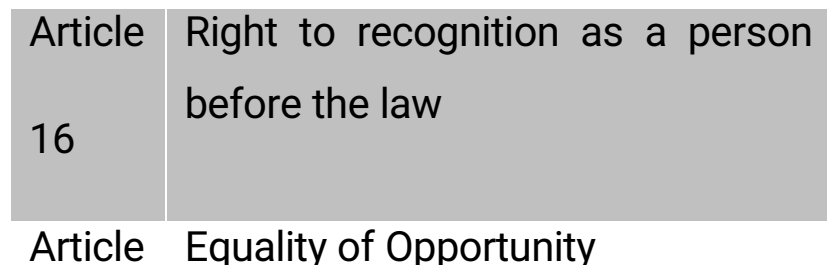

25

Article Equality before law

26

4. International Covenant on Article 1(1), 2

Economic, Social and Cultural 
Rights, 1966

5. Convention on the Rights of the Article 2(1), 2(2), 29(d)

Child, 1989

6. Convention on the Elimination of Article 1

All Forms of Discrimination

against Women, 1979

7. Declaration on the Elimination of Article 1(1), 1(2), 2(2), 4(2)

All Forms of Intolerance and of

Discrimination Based on

Religion or Belief, 1981:

8. Declaration on the Rights of Article 1(1), 1(2), 2-3, 4-7

Persons Belonging to National

or Ethnic, Religious and

Linguistic Minorities, 1992

9. African Charter on Human and Article 3(1)(2), 18(3)

Peoples' Rights, 1981

10. African Charter on the Rights Article 21(1)

and Welfare of the Child, 1990

11. American Convention on Human Article 1, 8(2), 24

Rights, 1969

12. Additional Protocol to the Article 3

American Convention on Human

Rights in the Area of Economic,

Social and Cultural Rights, 1988

13. Inter-American Convention on Article 6(a)(b), 7-9

the Prevention, Punishment, and

Eradication of Violence against

Women, 1994

14. Inter-American Convention on Article II,I (2) (a), Art. I (2)(b), 
the Elimination of All Forms of

Discrimination against Persons

with Disabilities, 1916

15. European Convention on Human Article 14

Rights, 1950

16. Framework Convention for the Article 1

Protection of

National Minorities,1994

\section{5: Equality and Non-Discrimination Provision under Constitution of Bangladesh:}

\begin{tabular}{|c|l|l|}
\hline SL. No. & \multicolumn{1}{|c|}{ Relevant Articles } & \multicolumn{1}{|c|}{ Provision } \\
\hline 1. & Preamble, Para-3 & $\begin{array}{l}\text { Further pledging that it shall be a fundamental aim } \\
\text { of the State to realize through the democratic } \\
\text { process a socialist society, free from exploitation } \\
\text { a society in which the rule of law, fundamental } \\
\text { human rights and freedom, equality and justice, } \\
\text { political, economic and social, will be secured for } \\
\text { all citizens. }\end{array}$ \\
\hline 2 & Article 19 & Equality of Opportunity \\
\hline 3. & Article 27 & Equality before law \\
\hline 4. & Article 28 & Discrimination on Grounds of Religion etc. \\
\hline 5. & Article 31 29 & Equality of Opportunity in Public Employment \\
\hline
\end{tabular}

\section{6: Vulnerable People:}

It is a great necessity to identify the people who are actually vulnerable in order to ensure equality of opportunity for them. But no exact definition or standard has set up for identifying them.

According to BPSC, "backward citizen means, the backward classes or community of citizens who are declared as backward by Government through gadget notification." ${ }^{24}$ Where Government is empowered to adopt such provisions. Conveyed by article 15(4), 28(4) and 29(3)(a) of the constitutions of peoples republic of Bangladesh.

In article 15(d) and 28(4) an indication of vulnerable people has given referring them

\footnotetext{
${ }^{24}$ Rule- 3(1) of the Bangladesh Civil Service Rules 2014. (SRO-NO-231-law/2014)
} 
'backward' citizen, including disabled, widows, orphan, children and women, provided that during debate on Article 15 in 1972 wounded freedom fighters and family of martyrs was specially mentioned for the benefit arises and Article 15(d) of then proposed constitution of Bangladesh. ${ }^{25}$

Beside constitution Legal Aid Act-2000 in its rules provided some criteria of vulnerable people in order to provide Legal Aid, According to Rule-2 of Legal Aid Rules 2001 Following persons will be considered as vulnerable people-

a. Any freedom fighter incapable of earning or partly incapable or jobless or whose yearly income is not more than taka 6,000.

Note: No such freedom fighter will be found as because they receive monthly remuneration of taka 10,000 from Government.

b. Any person who is receiving old age benefit.

c. Any helpless mother with V.G.D card.

d. Any women or children who are victims of illegal trafficking.

e. Poor widow, any poor women deserted by her husband

f. Any handicapped person with earning incapability

g. Any person who has been considered by the court financially incapable or poor, according to Person with Disability Welfare Act 2001 and High Court decision or a writ petition. ${ }^{26}$

"Physically challenged people are being entitled to have position in public service and to enjoy other facilities as per their qualification and for the sake of their welfare".

In practice by several gadget notification, and executive rules beside above mentioned community issues and grandchildren of freedom fighters. Women tribal community Trans Gender community is the beneficiary as backward community in Bangladesh.

\subsection{Conclusion:}

So it can be summed up that there are National and International Legal and moral obligations to ensure equality of Opportunity in Government services through identifying actual vulnerable groups.

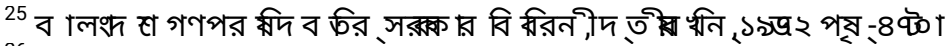

${ }^{26}$ BLAST and others v Bangladesh and others ['PSC Disability Discrimination' Case] Writ Petition No. 2932 of 2010.
} 


\section{Chapter-Four \\ Relation between Equality of opportunity in Public Service and Quota System in Bangladesh}

\subsection{Introduction:}

As because Quota system in Bangladesh public service was initiated with a vision to ensure Equality of Opportunity conveyed constitutional sprit. ${ }^{27}$

Here in this chapter in Right base Approach it will be examined. Whether the Quota system is able to ensure equality of opportunity in public service?

\subsection{Definition of Right based opportunity:}

There is no Universal Definition of Right based Approach. Different scholars and NGOs have defined the term differently. Keeping In mind the said topic a few of them are quoted below:

"A right based Approach deliberately and explicitly focus on people achieving the minimum conditions for living with dignity. It does so by exposing the root cause of vulnerability and marginalization and expanding the range of responses. It empowers people to claim and exercise their rights and fulfill their responsibilities. A Rights-based approach recognizes poor people as having inherent rights essential to livelihood security-rights that are validated by international standards and laws." ${ }^{28}$

"A Rights based approach to development describes situations not simply in terms of human needs on developmental requirements, but in terms of society's obligations, to respond to the inalienable rights of individuals, empowers people, to demand justice, as a right, not as a charity, and gives Communities a normal basis from which to claim international assistance when needed. ${ }^{29}$

In 2003 UN worked to adopt a common understanding of a right based approach and six main principles were given preference .The following basic principles, Universality, Accountability, Participation, Indivisibility and Non-Discrimination form the basis for action in a rights based approach.

Now I try to examine our existing Quota System based on the above mentioned principles of Right Based Approach.

\subsection{Freedom Fighter Quota:}

Previously Freedom Fighter Quota is discussed in chapter 2.4.1 here a comprehensive discussion will held regarding Universality, Accountability, Participation and Nondiscriminatory factors of Freedom Fighters Quota by answering following hypothetical Questions.

\footnotetext{
${ }^{27}$ Preamble and Article 29 of the constitution of peoples republic of Bangladesh.

${ }^{28}$ CARE 2000: 38) IDS Working Paper 234, What is the "rights-based approach" all about?

29 "What is the "rights-based approach" all about?",UN Secretary-General 1998): IDS Working Paper, Pg.234.
} 


\subsubsection{Whether the Quota provisions for Freedom Fighters is Universal?}

Reservation of positions in public service is common in most of the countries, especially in developing country like Bangladesh. But No other country who has liberated through a bloody war, reserved positions in public service for their Freedom Fighters in general, considering them as vulnerable or backward groups. So in test of Universality 'Freedom Fighters' fails to pass. Moreover including offspring and Grand Children's of Freedom Fighters as beneficiary of this Quota make the System Unique.

\subsubsection{Whether the Freedom Fighters Quota in Bangladesh Public Service is compatible with the Principle 'Participation and Inclusion' of right based approach:}

According to the United Nations Declaration on the Right to Development 'Participation should be active, free and meaningful'. ${ }^{30}$ The declaration also emphasizes in the fair distribution of the benefits resulting from the process.

The Freedom Fighters Quota in Bangladesh Public Service was initiated to ensure Participation of our brave freedom fighters with their patriotic sprit in nation building process. But the following table reveals the actual scenario.

Table: Candidates belong to freedom fighters category: ${ }^{31}$

\begin{tabular}{|c|c|c|c|}
\hline Year & $\begin{array}{l}\text { Quota reserved for } \\
\text { freedom fighter }\end{array}$ & $\begin{array}{l}\text { Actual availability (in } \\
\text { number) }\end{array}$ & $\begin{array}{l}\text { Actual availability (in } \\
\text { percentage) }\end{array}$ \\
\hline 1982 & $30 \%$ & 7 & $7.4 \%$ \\
\hline 1983 & $30 \%$ & 3 & $13.4 \%$ \\
\hline 1984 & $30 \%$ & 8 & $7.4 \%$ \\
\hline 1985 & $30 \%$ & 5 & $1.3 \%$ \\
\hline 1986 & $30 \%$ & 1 & $.08 \%$ \\
\hline $1989-1990$ & $30 \%$ & 1 & \\
\hline
\end{tabular}

With the above situation and consequences of the provision of keeping vacant of the reserved position seriously hampered others right to participation. Later on offspring and grandchildren of freedom fighters were included in the beneficiary list of freedom fighters quota in case of non-availability of freedom fighters, which raise question how they are competent to deserved the said quota?

Though the graph of availability in freedom fighter quota has increased after inclusion of offspring and grand children of freedom fighter in the quota but due to carry forward vacant reserved position and implementing Quota system from preliminary stage ${ }^{32}$ will exclude a huge number of general candidates from the race in very beginning stage.

\footnotetext{
${ }^{30}$ A Rights-Based Approach to Development by Inter Action, available at <www.interaction.org $>$, last accessed $18^{\text {th }}$ March, 2016.

${ }^{31}$ BPSC Annual Report, 1990 \& 1991.

32 BPSC Annual Report, 2015
} 


\subsubsection{Whether the existing "freedom fighter quota" in compatible with the principle of non-discrimination:}

In chapter 3.2 the principle of non discrimination has discussed, where some standards have set by the European Court $^{33}$ to test any treatment whether it is non-discriminatory or not?

Firstly, though the quota for the freedom fighters was initiated with an aim to develop their life standard and to recognize their sacrifice and patriotism, at present, after 45 years of liberation it loses its very perspective.

Secondly, the ratio of actual availability against reserve positions under freedom fighters quota shows that $30 \%$ reservation in this section is too big than reality.

Thirdly, carry forward vacant positions under freedom fighters quota and proposed implementation of quota from preliminary stage is seriously against the principal of nondiscrimination.

Finally, in a corruption prone third world country like Bangladesh-Identification of real freedom fighters and transparent distribution of reserved positions among them is still a far reality. In fact the reality is after 45 years of independence we are still confused about the definition of freedom fighter and their age limit.

\subsubsection{Whether the freedom fighters can be considered as vulnerable person: How prestigious it is considering all freedom fighters and theirs heirs as vulnerable person?}

The continuation of said Quota system at a huge margin in public service up to their second generation for a indefinite time give birth to that question.

In question of law, our freedom fighters by no means considered as vulnerable people as they get monthly remuneration and all of them are not from backward class, there is no direct provisions regarding freedom fighters Quota in our constitution, even no mentioning of such matter in the debate on constitution-1972. ${ }^{34}$

On the other hand, practically the honor of our brave freedom fighters has been hampered due to deprivation of mass people, especially millions of job seeker and their family as consequences of freedom fighters Quota at a large scale.

\subsubsection{Whether representation from freedom fighters as well as their wards are actually been filled up by the true freedom fighters on their wards?}

This type of unpleasant and embracing question exists because fact is that a large number of fake freedom fighters have been identified and sacked from public service. Another reality

\footnotetext{
${ }^{33}$ case 'Relating to Certain Aspects of the Laws on the Use of Languages in Education in Belgium , Application Nos. 1474/62, 1677/62, 1691/62, 1769/63, 1994/63, 2126/64, Judgments of 23 July 1968)

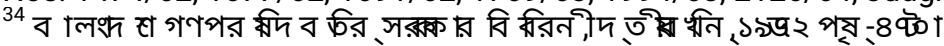


is that still we have not have a complete and accurate list of freedom fighters though 45 years have already passed after liberation. Most unfortunate things may be the definition of freedom fighters is still questioned. In such a situation in a corruption prone third world country like Bangladesh we cannot say confidently that all the freedom fighters and their heirs are real.

\subsubsection{Whether quota system is compatible with the spirit of our great liberation war:}

The spirit of liberation war is narrated in the $3^{\text {rd }}$ paragraph of preamble of the Constitution at Peoples Republic of Bangladesh, "pledging that it shall be a fundamental aim of the state to realize through the democratic process a socialist society free from exploitation a society in which the rule of law fundamental human right and freedom, equality and justice, political, economic and social will be secured for all citizens." Rationality at initiation freedom fighter quota in order to rewarding their braveness and supporting family members at our martyrs is never been questioned. But despite of abolishing the quota gradually as per the recommendation of $\mathrm{PSC}^{35}$ in 1997 it has been extended up to grandchildren of freedom fighters for a indefinite time. Further steps have been taken to carry forward the vacant position in case of non-availability and implementing the quota from the preliminary stage.

These steps make the quota of freedom fighters questioned in a ground that whether it is compatible with the spirit of our liberation war in establishing a non-discriminatory society?

\subsection{District Quota:}

In order to remove disparity in then Pakistan the district or region base quota was first initiated immediately after 1947 which got constitutional at recognition in 1956. It was continued in Bangladesh amounting $40 \%$ of total position. Though at present the figure has reduced at $10 \%$ but in true sense all $50 \%$ out of $55 \%$ reserved position are distributed among the district proportionately according to the population.

Here the rationality of district quota and district based implementation process will be examined according to principal of right based approach.

\subsubsection{Whether the 'District Quota' is universal:}

Except SAARC countries the reservation system in public service based on 'region or district' is rare. In Pakistan $92.5 \%$ of positions are distributed among six provinces ${ }^{36}$ where disparity exists in large scale among those province regarding ethnicity and socio- economic condition. Sri Lanka distributed positions equivalent to population ratio rather reserving any position $^{37}$ i.e if any district have $15 \%$ of total population than the candidates of that district deserve $15 \%$ of total positions.

In Nepal $4 \%$ of positions have been reserved for rural/Backward places. ${ }^{38}$ Rather a wide application.

There are no reservation based on region in India Centrally except Kashmir but every province reserved a certain percentage of positions for their own provincial candidates. ${ }^{39}$

So it is clear that no other country except Bangladesh have such complex implementable reservation regarding Region/District.

\footnotetext{
${ }^{35}$ Government of Bangladesh (1997), Report of the Pay and Service Commission, Part-1, Cabinet Division, Dhaka.

${ }^{36}$ https://en.m.wikipedia.org/wiki/Quota_System_in_Pakistani

${ }^{3 /}$ http://thakshana.nsf.ac.lk/slstic/NA-284/NA-284.pdf

${ }^{38} \mathrm{http} / / /$ www.moga.gov.np/main/images/pdf/Inclusion\%20in\%20Civil\%20Service\%20

-\%20lssues\%20and\%20Initiatives.pdf

${ }^{39}$ https://en.m.wikipedia.org/wiki/Reservation_in_India
} 


\subsubsection{Whether the districts that are considered backward are getting proportionate representation?}

In an interview with daily star ${ }^{40}$ for men cabinet Secretary and advisor of former caretaker government said, "District Quota for public service was introduced when the country had just 17 or 19 districts. But this Quota creates problem now that the country has 64 districts."

To justify the nature of problems created by District Quota the following table will help us. Table: The Distribution of District Quota ${ }^{41}$

\begin{tabular}{|l|c|c|}
\hline \multicolumn{1}{|c|}{ Name of District } & Required percentage & Position among all \\
\hline Dhaka & 5.59 & $1^{\text {st }}$ biggest \\
\hline Chittagong & 5.22 & $2^{\text {nd }}$ Biggest \\
\hline Comilla & 3.87 & $3^{\text {rd }}$ Biggest \\
\hline Mymensing & 3.65 & $4^{\text {th }}$ Biggest \\
\hline Bogra & 2.45 & $5^{\text {th }}$ Biggest \\
\hline Bandarban & 0.22 & $1^{\text {st }}$ lowest \\
\hline Khangracharri & 0.33 & $2^{\text {nd }}$ Lowest \\
\hline Rangamati & 0.38 & $3^{\text {rd }}$ Lowest \\
\hline Meherpur & 0.46 & $4^{\text {th }}$ Lowest \\
\hline Norail & 0.62 & $5^{\text {th }}$ Lowest \\
\hline
\end{tabular}

From the above table it is found that the people from Dhaka district get the highest Quota facility while Bandar ban is the lowest, but in practice as because Dhaka is the capital of Bangladesh almost all part of Dhaka district is covered by two city corporation and all administrative and economic activity of Bangladesh is Dhaka centered, people of this district enjoys highest facility of education and other government and non-government service while in term of Geographic location, Residence of Ethnic Minorities and Briars imposed by CHT Act. $^{42}$

People of CHT enjoy lowest opportunity of education and other government service. So how it is equitable or non-discriminatory to distribute reserved positions among district in such a way?

\subsubsection{Whether the person who is getting the Quota facility from the backward District is coming from a poor family or is from a well off family.}

May be the answer of this question is unknown to BPSC as well as government because to distribute the position among prescribed district is a impossible task to BPSC. Where identifying actual backward community is a remote dream. Recognizing this fact the public

\footnotetext{
${ }^{40}$ Daily Star, July 13, 2013.

${ }^{41}$ Computer Center, Ministry of Public Administration.

${ }^{42}$ Chittagong Hill Tracts Land Dispute Resolution Commission (Amendment) Act 2016
} 
service commission admitted in its annual report 2015 that, "it is humanly impossible to flawlessly solve the multi-dimensional equations regarding the cadre choices of candidates, as well as the numerical Quota limits impose to districts/Division within the given time." In a corruption prone country like Bangladesh such a complex and hazy system in recruiting the important most positions of the state service motivates corruption during implementing the process. Thus the recruitment of actual vulnerable person under the Said quota provision becomes more difficult.

\subsection{Woman quota:}

There is no question about the rationality and legitimacy of initiating women quota as because it is directly instructed by the constitution ${ }^{43}$ and also recommended by international declaration and treaty and national policy.

Further more in almost all countries women quota is recognized in public service. For example a statistic has been given in the table below.

\begin{tabular}{|l|l|l|l|l|l|l|l|l|}
\hline $\begin{array}{l}\text { Name of } \\
\text { country }\end{array}$ & $\begin{array}{l}\text { Nepa } \\
\mathrm{I}\end{array}$ & $\begin{array}{l}\text { Pakista } \\
\mathrm{n}\end{array}$ & India & USA & UK & $\begin{array}{l}\text { German } \\
\mathrm{y}\end{array}$ & Japan & $\begin{array}{l}\text { Canad } \\
\mathrm{a}\end{array}$ \\
\hline $\begin{array}{l}\text { Reserved } \\
\text { Percentag } \\
\text { e }\end{array}$ & $33 \%$ & $10 \%$ & $\begin{array}{l}\text { Defined by } \\
\text { the } \\
\text { provincial } \\
\text { Governmen } \\
\mathrm{t}\end{array}$ & $\begin{array}{l}\text { Affirmativ } \\
\text { e Action }\end{array}$ & A.A & A.A & A.A & A.A \\
\hline
\end{tabular}

In south Asia countries trend of specific reservation has seen i.e. Nepal reserved $33 \%{ }^{44}$, Pakistan $10 \%{ }^{45}$ and India also reserve position for woman which are define by the provincial Government within a limit ${ }^{46}$. In developed countries like Japan, UK, Canada, USA, this term is used as 'Affirmative Action' which tends to emphasize not specific quotas but rather ' targeted goals' to address past discrimination in a particular institution on in broader society through 'good faith efforts to identify select and train potentially qualified minorities and woman"47

So it can be said that the quota provision for woman is compatible with the principal Universality of right based approach.

\subsubsection{Whether the allocated quota in public service is functioning as a tool of removing discrimination towards woman?}

For the potential development of a country the participation of women in all sphere of states file is very important ${ }^{48}$ We can say in the voice of our national poet Kazi Nazrul Islam , "women did half of the task in all of the greatest achievement in human society."

\footnotetext{
${ }^{43}$ Article 28 (4) of the Constitution of Peoples Republic of Bangladesh.

${ }^{44}$ http://www.moga.gov.np/main/images/pdf/Inclusion\%20in\%20Civil\%20Service\%20 $-\% 20$ lssues\%20and\%20Initiatives.pdf

${ }^{45}$ https://en.m.wikipedia.org/wiki/Quota_System_in_Pakistani

${ }^{46}$ https://en.m.wikipedia.org/wiki/Reservation_in_India

${ }^{47}$ https://en.m.wikipedia.org/wiki/Affirmative_action_in_the_United_States

${ }^{48} \mathrm{http}$ ://www.unwomen.org/what-we-do/leadership-and-political-participation last accessed $20^{\text {th }}$ March, 2016.
} 
Although participation of women in work force is increasing but the pace is not satisfactory. Following table contains statistics supporting this fact

Table: distribution cadre officers working in decision making post ${ }^{49}$

\begin{tabular}{|l|c|c|c|c|}
\hline \multirow{2}{*}{ Rank } & \multicolumn{2}{|c|}{ BCS Officers } & Total & Female percentage \\
\cline { 2 - 5 } & Male & Female & & \\
\hline Secretary & 52 & 2 & 54 & 3.85 \\
\hline Additional Secretary & 162 & 13 & 175 & 7.43 \\
\hline Joint Secretary & 395 & 35 & 435 & 8.14 \\
\hline Deputy Secretary & 1245 & 169 & 1414 & 11.95 \\
\hline
\end{tabular}

Above table shows a traditional picture but if we analyze the participation and success rate in Secondary and Higher Secondary School Certificate exams it reveals that in recent years female students are more successful than male student but they are not seen in the final race as because still they are better considered as housewife, Steps have to be taken for using these potentials in nation building process. Which could be best possible by extended current quota provision for them, thus discrimination towards them might be reduced a bit?

\subsubsection{Whether the selected women in civil service under quota provision are from educated and privileged family?}

Besides re-thinking about the quota figure allocated for women, it will also be taken into consideration whether the candidate are from well off family or not?

Because in our society a clear distinction exist regarding thinking and treatment process around women between educated well off family and typical lower middle class family. So a female born and grown up in a modern family with all support and facility and a female born and grown up in a poor family in rural area being educated by struggle cannot be treated equally in question of getting any privileges.

Without such a mechanism of filtering actual vulnerable women the existing or modified quota for women could not be considered as participatory and Non-discriminatory.

\subsection{Tribal Quota:}

Tribes or Ethnic Minority community are considered as backward community all around the world as they lives in remove area and love to lead their traditional life, They look behind from modern education and development activity. But things are changing - Ethnic minorities at present come forward to take proper education and wants to participate in the main work-force. Though our constitutional provision under Article 29 (3) (a) read with

\footnotetext{
${ }^{49}$ Ministry of Public Administration, 2007, 2008 and 2009. ${ }^{49}$
} 
Article 29 is to make special provision to facilitate backward community beyond religion , race, caste, sex or place of birth but we need 14 years after liberation to facilitate the backward tribal community with $5 \%$ reservation of position in public service.

Reservation positions in public service for ethnic minorities in most of the countries are widely recognize, Following table shows data supporting this statement-

Table: Quota reserved for ethnic minorities in different countries 


\begin{tabular}{|l|c|l|c|c|c|l|l|}
\hline $\begin{array}{l}\text { Name of } \\
\text { country }\end{array}$ & Nepal $^{\mathbf{5 0}}$ & Pakistan $^{\mathbf{5 1}}$ & Canada $^{\mathbf{5 2}}$ & Japan $^{\mathbf{5 3}}$ & China $^{\mathbf{5 4}}$ & USA $^{\mathbf{5 5}}$ & India $^{\mathbf{5 6}}$ \\
\hline $\begin{array}{l}\text { Reserved } \\
\text { Percentage }\end{array}$ & $27 \%$ & $4 \%$ & $6 \%-45 \%$ & $5 \%$ & $8 \%$ & $\begin{array}{l}\text { Termed as } \\
\text { affirmative } \\
\text { action } \\
\text { without } \\
\text { specifying } \\
\text { figure }\end{array}$ & $\begin{array}{l}\text { Within a limit } \\
\text { of total quota } \\
\text { provincial } \\
\text { Govt } \\
\text { determine the } \\
\text { figure }\end{array}$ \\
\hline
\end{tabular}

So the Quota for ethnic minority or tribal community is compatible with the principle of Universality of Right based Approach.

\subsubsection{Whether the Tribal Quota being filled by the all Tribes Proportionate to the particular Tribes Population size to the total Tribal Population:}

There are 48 Tribal community in Bangladesh having 15,44,141 population in Number. ${ }^{57}$

Most of them lives in CHT, Mymansingh, Netrokona, Rajshahi and Sylhet District. The socio economic conditions of these tribal communities are not same. Among them Chakmas are well ahead in terms of human development index compared to other tribal populations. Due to average distribution of tribal Quota this particular tribe is mostly benefited, According to Amartya Sen 'It is a poor substitute.'

More over because of average distribution it fails to comply with the Right Based Approach principle 'Participation and inclusion', as because without proper assessment of each tribe's socio-economic conditions and population allotted positions are distributed on average.

\subsubsection{Whether the allotted percentage for Tribal community is adequate?}

Though allotment is $5 \%$ of total positions but due to implementation complexity the number of actual recruitment is curtailed even though their performance is better than other quota candidates. It happens because during quota implementation firstly allotted quotas are distributed among the districts according to their population where $\mathrm{CHT}$ districts get lowest priority; as a result most of the tribal community lives in $\mathrm{CHT}$ districts are the sufferer by the process.

\footnotetext{
${ }^{50}$ http://www.moga.gov.np/main/images/pdf/Inclusion\%20in\%20Civil\%20Service\%20 -\%20lssues\%20and\%20Initiatives.pdf

${ }^{51}$ https://en.m.wikipedia.org/wiki/Quota_System_in_Pakistani

52 https://www.quora.com/Which-countries-other-than-India-have-caste-based-reservation-systems

53 https://www.quora.com/Which-countries-other-than-India-have-caste-based-reservation-systems

54 https://www.quora.com/Which-countries-other-than-India-have-caste-based-reservation-systems

${ }^{55}$ https://en.m.wikipedia.org/wiki/Affirmative_action_in_the_United_States

56 https://en.m.wikipedia.org/wiki/Reservation_in_India

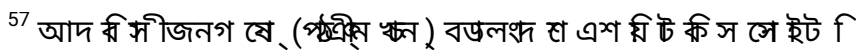


So impact of district quota and implementation process of existing quota system is not compatible with the principle 'Non-Discrimination' of right based approach and thus it fails to ensure equality of opportunity for the tribal community in Bangladesh.

\subsection{Handicapped Quota:}

Physically Challenged People and Third Gender Community are being served 1 percent reservation of vacant position after fulfilling other quotas in case of Non-Availability.

Although in any consideration these communities are considered as most vulnerable by National and International Government but they are discriminated in all sectors since emergence of Bangladesh. Following facts reveals the actual status of physically handicapped person in securing position in public service and ensuring equality of opportunity.

Firstly In most of the country rather Bangladesh a notable portion of positions are reserved for the persons with disabilities but in Bangladesh-

$>$ before 1985 in $\left(3^{\text {rd }}\right)$ and $\left(4^{\text {th }}\right)$ class job,

$>$ before 2010 in $1^{\text {st }}$ and $2^{\text {nd }}$ class job and

$>$ Still in post of Assistant Judge they are not allowed to sit for the exam having proper educational Qualification.

In $1985,10 \%$ quota was allocated in $3^{\text {rd }}$ and $4^{\text {th }}$ class job for the persons with disabilities, in 2012 through a circular bearing memo no-05.00.0000.170.07.957.11-15 dated-12/1/2012 decided to preserve a quota of 1 percent in $1^{\text {st }}$ and $2^{\text {nd }}$ class government services in government offices, Autonomous/semi-Autonomous bodies and different Corporations including BCS cadres. Provided that the 1\% Quota of PWDs will be accommodated only in those places where in other quotas would not be filled up". Unfortunately implementing these circular some applicants had to file a writ petition. ${ }^{58}$ In $34^{\text {th }}$ BCS only 3 person was recruited Quota of total 2159 positions and no person was recruited in non-cadre $1^{\text {st }}$ class and $2^{\text {nd }}$ class position, which proves the scenario of that so called reserved quota. Despite this circular provision under section 6(2) of Disability welfare Act-2001 and schedule 'cha' of the said Act and Fundamental Rights conferred by Article-27, 29 and 40 the Bangladesh Judicial Service Commission denying to allow person with disability to apply for the post 'Assistant Judge' recruited by them, though there is examples in USA and UK of becoming High Court Division Judge by a Blind Person. ${ }^{59}$

Secondly, On the other hand third gender community are the fresh citizens of Bangladesh as they are recognize as citizen by enlisted as Voter after 45 years of liberation They are far away from the race of achieving a civil service position.

The provisions and treatment towards PWDs is very much inconsistent with the principle of equality of opportunity. Actually legislative and executive authority consider taking any step for the benefit of PWDs as charity rather recognize their constitutional Right and Right to

\footnotetext{
${ }^{58}$ BLAST and others v Bangladesh and others ['PSC Disability Discrimination' Case] Writ Petition No. 2932 of 2010

${ }^{59}$ https://login.thetimes.co.uk/?gotoUrl=http\%3A\%2F\%2Fwww.thetimes.co.uk\%2Ftto\%2Fopinion\%2Fobituaries\%2 $\mathrm{F}$
} 
Live with dignity. They think that these persons are suitable for $3^{\text {rd }}$ and $4^{\text {th }}$ class job without considering their academic qualification, so it can be concluded that physically Handicapped quota is fruitless and not compatible with the principles of Right based Approach thus in no way it is able to ensure equality of opportunity in public service for the persons with Disability.

\subsection{Overall Evaluation of quota system:}

From the above discussion in this chapter we can identify following characteristics of existing quota system in Civil Service of Bangladesh.

a. Percentage of Freedom Fighter Quota is too large

b. Continuation of Freedom Fighter Quota is questioned

c. Extension of Freedom Fighter Quota up to their grand children is inconsistent with the principle of Non-Discrimination.

d. Earmarked these quota with ward and carry forward of vacant position in case of non availability makes the process complex and discriminatory,

e. Proposed implementation of Quota from preliminary stage will exclude general candidates from very beginning and physical Handicapped people to get any position because no vacancy will create in case of non-availability.

f. District quota is seems un-necessary as present socio-economic condition of the state where it has made the whole recruitment process complex and create discrimination among urban and rural candidates.

g. Women quota is little inadequate as they are still backward in many sector

h. Tribal quota is inadequate as their socio-economic condition and proportionate distribution of allotted position is necessary among all tribal.

i. $1 \%$ quota for physically handicapped persons is a vague term as it is not direct reservation rather conditional, surprisingly and unfortunately they have not had the opportunity to even apply in all public service for which they are compatible i.e. BJSC yet. Provisions and Treatment towards PWD is very much discriminatory and inconsistent in ensuring equality of opportunity.

\subsection{Status of the largest portion who are recruited in public service on basis at} merit:

There is no other country rather Bangladesh and Pakistan where more than $50 \%$ positions in public service are being reserved. Our sprit of liberation war narrated in the $3^{\text {rd }}$ paragraph of the preamble of our constitution is to establish an exploitation free society. But the said quota system is very much inconsistence with the principles of non-discrimination, Participation and inclusion universality and accountability as statistics shown- ${ }^{60}$

In the five BCS exam from 2005-2012, PSC recommended appointing 3,179 successful

${ }^{60}$ BPSC Annual Report, 2005-2015. 
candidates to the posts of 15 class- 1 General Cadres out of them , 1493 were picked on merit and 1686 from different quotas. ${ }^{61}$

This situation for the merit based candidates will be worst it as per recommendation in BPSC maintained from preliminary stage.

"Job seekers, too, on many occasions have protested the system calling it discriminatory. They observe many talented candidates fall to join the civil service due to the quota provision." ${ }^{62}$

\subsection{Conclusion:}

So by no means existing quota provisions in civil service of Bangladesh is compatible with the principles of right based approach and able to ensure equality of Opportunity in Government Services in Bangladesh.

${ }^{61}$ BPSC Annual Report, 2015.

${ }^{62}$ Daily Star, July 13, 2013. 


\section{Chapter- Five}

\section{Recommendations and Conclusion}

\subsection{Recommendation:}

a. In total, the maximum amount of reservation must not exceed $50 \%$ of total position.

b. The provisions of District Quota should be revised and can only be preserved for the backward pheniferal districts with a redueul figure.

c. The implementing process by earmarked the 'Freedom Fighter' and 'Women Quota' should be abolished.

d. A time frame should fixed regarding extinction of Freedom Fighter Quota. The quantity and provision of extending the area of the quota up to Grand Children of Freedom Fighters should be revised.

e. Women and Tribal Quota should be distributed among true quota proportionate to the population and socio economic Condition of the tribes. The portion of reservation of this quota can be increased a bit.

f. Increased direct portion of reservation should be ensured for the Physically Handicapped Community Opportunity of Participation in all suitable Public Services have to ensure as a fundamental Rights for PWDs.

g. Inclusion of reservation for the people of former Enclaves and Climate Refugees is recommended.

\subsection{Conclusion:}

In conclusion it can be said that by no means the existing Quota System in Government Services is able to ensure 'Equality of Opportunity and Compatible with the principles of Rights-based Model. As consequences our administrative positions are continuously filled up with the back benchers which meritorious guys find their career in private sectors or outside country. Some of them often become frustrated by this deprivation and commit suicide and involve with anti-social activities.

So to utilize the best brains in nation building process and establish a exploitation free society as per the spirit of our Liberation War as well as ensure 'Equality of Opportunity in Government Services the current Quota System should be revised immediately. 


\section{Bibliography}

1. "Women in Bangladesh Civil Service: Present Status and Challenges", Ara, Fardaus, Society \& Change, Vol IV, No.2, April-June 2012

2. "Equal Opportunities for Women and Men Monitoring law and practice in Hungar,Andrea Krizsán, Enikõ Pap,Foundation for the Women of Hungary, 2005.

3. "Discrimination LaW',Fredman, Sandra, Oxford University Press, Oxford, 2002, Oxford University Press, Oxford, 2002.

4. "The Concept of Discrimination,"Holtmaat, Rikki, Academy of European Law Conference Paper, 2004

5. "The World Distribution of Household Wealth",James B. Davies, Susanna Sandstrom, Anthony Shorrocks, and Edward N. Wolff.

6. "Equality and Non-Discrimination" in Feldman, David (ed.) "English Public Law",McCrudden, Christopher, Oxford University Press, Oxford, 2004

7. "The Empty Idea of Equality", Westen, Peter, Harvard Law Review, Vol. 95, No.3, 1982

8. "Dignity and Equality", Human Rights Law Review, Vol. 7, No.2, 2007

9. Constitution of the People's Republic of Bangladesh,

10. Universal Declaration on Human Rights (adopted 10 December 1948)

11. International Covenant on Civil and Political Rights (adopted 16 December 1966, entered into force 23 March 1976) 999 UNTS 171,

12. Cossey v UK [1990] Series A No. 184[2.7];

13. MohiuddinFarooqueVs. Bangladesh and others, 48 DLR HCD 438.

14. Aristotle, 3 EthicaNicomachea, 112-117, 1131a-1131b, Ackrill, J. L. and Urmson J. 0. (eds.), W. Ross translation, Oxford University Press, 1980

15. (CARE 2000: 38) IDS Working Paper 234, What is the "rights-based approach" all about?

16. 'What is the "rights-based approach" all about?",UN Secretary-General 1998): IDS Working Paper,

17. A Rights-Based Approach to Development by InterAction, available at $<$ www.interaction.org $>$, last accessed $18^{\text {th }}$ March, 2016

18. Bangladesh Public Service Commission (1995), Annual Report, Government of the People's Republic of Bangladesh, Dhaka. 
19. Bangladesh Public Service Commission (2002), Annual Report, Government of the People's Republic of Bangladesh, Dhaka.

20. Cabinet Division,(1977), Report of Pay and Service Commission (Volume1, Government of the people's Republic of Bangladesh, Dhaka.

21. Government of the People's Republic of Bangladesh (1972), The Constitution of the People's Republic of Bangladesh, Dhaka.

22. Government of Bangladesh (1997), Report of the Pay and Service Commission, Part-1, Cabinet Division Dhaka.

23.Government of the People's Republic of Bangladesh ,(2000), Public Administration for $21^{\text {st }}$ Century, Report of the Public Administration Reforms Commission, vol.-1,Dhaka.

24. Government of the People's republic of Bangladesh, (2000) Report of the Public Administration Reform Commission, vol.-2, June 2000.

25. Government of the People's Republic of Bamgladesh, (2001) Statistics of Civil Officers and staff of the Government of the People's Republic of Bangladesh @001,Vol.2,June 2000. 